\title{
MENINGKATKAN KESADARAN DAN PENGETAHUAN ORANG TUA MENGENAI BAHAYA FLU BIASA PADA ANAK-ANAK DI DESA PEGUYANGAN KAJA - DENPASAR
}

\author{
I Putu Dedy Kastama Hardy ${ }^{1}$, Ni Luh Gde Ari Natalia YUdaha². \\ ${ }^{1}$ Universitas Dhyana Pura \\ ${ }^{2}$ Universitas Dhyana Pura
}

dedykastama@gmail.com,nengnatalia@gmail.com

\begin{abstract}
Abstrak
Berdasarkan data kunjungan dari Puskesmas III Denpasar Utara dan dari hasil brain storming yang kelompok kami lakukan, ditemukan angka kesakitan tertinggi yang ada Di Desa Peguyangan Kaja yaitu penyakit flu biasa merupakan salah satu penyakit yang paling banyak dengan jumlah penderita 622 orang pada data tahun 2020. Jika dilihat berdasarkan faktor resiko, faktor paling utama dari penyakit flu biasa adalah karena kurangnya kesadaran masyarakat dalam penerapan perilaku hidup bersih dan sehat (PHBS). Kemudian, dilihat dari faktor lingkungan juga mempengaruhi sumber berkembangnya suatu penyakit, karena kondisi sanitasi lingkungan yang buruk dapat membahayakan kesehatan masyarakat. Metode yang digunakan dalam mencapai tujuan program tersebut adalah dengan melakukan penyuluhan berupa pemberian materi PHBS (khusus perilaku masyarakat terhadap lingkungan sekitar dan pola makan) dan materi ISPA. Dari hasil pendataan yang telah dilakukan terhadap 30 responden dapat dilihat nilai rata-rata jumlah responden yang menjawab benar dan salah pada soal pre tes dan pos tes yaitu jumlah rata-rata pada soal pre tes untuk jawaban benar adalah 69,835\% dan untuk jawaban salah adalah 30,165\% sedangkan untuk jawaban benar soal post tes adalah $82,50 \%$ dan untuk jawaban salah adalah 17,50\% sehingga hal ini menunjukkan bahwa adanya peningkatan sebanyak 12,65\% terhadap soal pre tes dan post tes. Sedangkan impact dari program ini yaitu meningkatnya kesadaran \& pengetahuan orang tua terhadap pentingnya menjaga kebersihan lingkungan serta penerapan perilaku hidup bersih dan sehat (PHBS) karena hal ini merupakan salah satu penyebab terjadinya penyakit flu biasa yang merupakan gejala dari penyakit ISPA dimana hal ini juga akan berdampak pada meningkatnya status kesehatan di desa Peguyangan Kaja sehingga angka kejadian flu di Desa Peguyangan Kaja juga dapat menurun.
\end{abstract}

Kata Kunci : ISPA, Pada Anak, Penyuluhan

\section{PENDAHULUAN}

Desa Peguyangan Kaja merupakan salah satu desa di Kecamatan Denpasar Utara. Desa Peguyangan Kaja mempunyai luas wilayah sekitar 536,00ha, dengan batas-batas wilayah sebagai berikut, sebelah utara Desa Darmasaba, Kecamatan
Abiansemal, sebelah selatan Desa Peguyangan, Kecamatan Denpasar Utara, sebelah timur Desa Peguyangan Kangin, Kecamatan Denpasar Utara, sebelah barat Desa Ubung Kaja, Kecamatan Denpasar Utara. Desa Peguyangan Kaja terbagi ke dalam 11 banjar diantaranya, Banjar Gunung, Banjar Saih, Banjar Paang Tebel, Banjar Pondok, 
Banjar Punduhkulit, Banjar Uma Desa, Banjar Belusung, Banjar Dualang, dan Banjar Den Yeh. Iklim di Desa Peguyangan Kaja, yaitu curah hujan: 2.000,00 mm, jumlah bulan hujan: 6.00 bulan, kelembapan: 0.00, suhu rata-rata harian: $32.00 \mathrm{C}$, tinggi tempat dari permukaan laut: $200.00 \mathrm{mdl}$. Sesuai dengan data yang kami peroleh bahwa Desa Peguyangan Kaja mempunyai jumlah penduduk pada tahun 2020, dimana penduduk laki-laki berjumlah 3828 orang dan penduduk perempuan berjumlah 3943 orang. Sedangkan pada tahun 2019, penduduk laki-laki berjumlah 181 orang dan penduduk perempuan 185 orang. Persentase perkembangan penduduk, laki-laki 2014.92\% dan perempuan 2031.35\%. Kondisi perekonomian masyarakat yang ada di Desa Peguyangan Kaja sudah hidup berkecukupan, karena sebagian besar masyarakat yang ada di Desa Peguyangan Kaja memiliki mata pencaharian masing-masing. Penduduk yang bekerja laki-laki dengan jumlah 2332 orang dan perempuan dengan jumlah 1720 orang. Sedangkan penduduk yang tidak bekerja laki-laki dengan jumlah 1496 orang dan perempuan dengan jumlah 2223 orang.

Berdasarkan data yang di peroleh dari Desa Peguyangan Kaja dan Puskesmas III Denpasar Utara pada tahun 2020, diketahui bawah terdapat 10 penyakit yang ada di Puskesmas III Denpasar Utara dilihat dari jumlah pasien yang datang ke Puskesmas III Denpasar Utara setiap harinya yaitu; 243 orang penderita sakit kepala, 66 orang penderita artritis, 221 orang penderita dermatitis kontak alergi, 53 orang penderita infeksi saluran pernafasan, 20 orang penderita DBD, 102 orang penderita hipertensi esensial (primer), 41 orang penderita hiperkolesterol murni, 622 orang penderita flu biasa, 209 orang penderita faringitis, dan 310 orang penderita demam tidak spesifik. Dari data penyakit yang kami dapatkan di Desa Peguyangan Kaja dan Puskesmas III Denpasar Utara di sebabkan oleh beberapa faktor, yaitu pada penyakit sakit kepala biasanya di sebabkan oleh stress, alergi, bahkan karena masalah asupan gizi.
Penyakit artritis terjadi ketika jaringan tulang rawan mengalami peradangan, sehingga mengakibatkan gangguan fungsi sendi. Penyakit dermatitis kontak alergi di sebabkan karena zat tertentu misalnya seperti sabun, kosmetik, perhiasan, dll. Penyakit infeksi saluran pernafasan bisa menyerang setiap bagian saluran pernapasan seperti rongga hidung, sinus, tenggorokan, bronkus, bronkiolus dan paru-paru. Infeksi saluran pernapasan disebabkan oleh bakteri dan virus, bakteri, jamur dan parasit kondis ini rentan di derita oleh anak-anak. Penyakit DBD disebabkan oleh virus dengue yang ditularkan oleh nyamuk Aedes aegypti. Penyakit hipertensi essensial (peningkatan tekanan darah), biasanya terjadi pada seseorang yang memiliki riwayat hipertensi, lebih sering muncul di usia 40- an. Penyakit hiperkolesterol murni disebabkan oleh faktor genetik dan gaya hidup kurang sehat. Penyakit flu biasa disebabkan oleh virus influenza yang dapat menyerang hidung, tenggorokan dan paru-paru. Flu sangat umum terjadi saat pergantian iklim.penyakit ini sangat mudah menular melalui ke orang lain lewat udara. Penyakit faringitis (peradangan pada tenggorokan atau faring) umumnya disebabkan oleh infeksi virus. Dilihat dari jumlah pasien yang datang ke Puskesmas III Denpasar Utara setiap harinya yaitu; 243 orang penderita sakit kepala, 66 orang penderita artritis, 221 orang penderita dermatitis kontak alergi, 53 orang penderita infeksi saluran pernafasan, 20 orang penderita DBD, 102 orang penderita hipertensi esensial (primer), 41 orang penderita hiperkolesterol murni, 622 orang penderita flu biasa, 209 orang penderita faringitis, dan 310 orang penderita demam tidak spesifik. Dari data penyakit yang kami dapatkan di Desa Peguyangan Kaja dan Puskesmas III Denpasar Utara di sebabkan oleh beberapa faktor, yaitu pada penyakit sakit kepala biasanya di sebabkan oleh stress, alergi, bahkan karena masalah asupan gizi. Penyakit artritis terjadi ketika jaringan tulang rawan mengalami peradangan, sehingga mengakibatkan gangguan fungsi sendi. Penyakit dermatitis kontak 
alergi di sebabkan karena zat tertentu misalnya seperti sabun, kosmetik, perhiasan, dll. Penyakit infeksi saluran pernafasan bisa menyerang setiap bagian saluran pernapasan seperti rongga hidung, sinus, tenggorokan, bronkus, bronkiolus dan paru-paru. Infeksi saluran pernapasan disebabkan oleh bakteri dan virus, bakteri, jamur dan parasit kondis ini rentan di derita oleh anak-anak. Penyakit DBD disebabkan oleh virus dengue yang ditularkan oleh nyamuk Aedes aegypti. Penyakit hipertensi essensial (peningkatan tekanan darah), biasanya terjadi pada seseorang yang memiliki riwayat hipertensi, lebih sering muncul di usia 40- an. Penyakit hiperkolesterol murni disebabkan oleh faktor genetik dan gaya hidup kurang sehat. Penyakit flu biasa disebabkan oleh virus influenza yang dapat menyerang hidung, tenggorokan dan paru-paru. Flu sangat umum terjadi saat pergantian iklim.penyakit ini sangat mudah menular melalui ke orang lain lewat udara. Penyakit faringitis (peradangan pada tenggorokan atau faring) umumnya disebabkan oleh infeksi virus.

Berdasarkan hasil brain storming dengan Puskesmas dari data 10 prioritas masalah penyakit yang dapat diliat dari data kunjungan di Puskesmas III Denpasar Utara dan data kesakitan di Desa Peguyangan Kaja. Kami mendapatkan 3 prioritas masalah penyakit dimana dalam menentukan 3 prioritas masalah penyakit ini kami menentukan dengan melakukan tahapan brain storming dengan 5 kriteria yang kami gunakan, yaitu: kemampuan menyebar dan menular, sanitasi lingkungan yang buruk, gaya hidup yang tidak sehat, faktor yang dipengaruhi oleh perubahan cuaca, dan gangguan rasa nyaman pada pasien. Dimana prioritas pertama penyakit flu biasa, prioritas kedua DBD, prioritas ketiga faringitis.

Dilihat dari tingginya kasus berdasarkan data kunjungan Puskesmas III Denpasar Utara, yaitu penyakit flu biasa dimana angka kesakitan flu biasa setiap tahunnya terus memasuki peringkat 10 besar penyakit. Dimana kasus flu biasa ini juga masuk ke dalam gejala dari penyakit ISPA. Banyaknya kasus penderita flu biasa tersebut terjadi karena kurangnya kesadaran masyarakat dalam penerapan perilaku hidup bersih dan sehat (PHBS). Kemudian, dilihat dari faktor lingkungan juga mempengaruhi sumber berkembangnya suatu penyakit, karena kondisi sanitasi lingkungan yang buruk dapat membahayakan kesehatan masyarakat.

Maka dari itu, diperlukan alternatif pemecahan masalah terkait dengan angka kejadian flu biasa yang terus meningkat. Alternatif yang kelompok kami gunakan adalah kegiatan sosialisasi yang sasaran utama dari kegiatan sosialisasi yaitu kepada orang tua yang memiliki balita karena di lihat dari kondisi pada anak kecil yang dimana daya tahan tubuh anak balita masih belum terbentuk sempurna sehingga hal itulah yang dapat menyebabkan anak balita sangat rentan terkena flu, jika tidak di tangani secara cepat maka dapat menyebabkan ISPA. Pada kegiatan sosialisasi ini kami akan berkolaborasi dengan posyandu setempat. Kegiatan ini akan dilaksanakan di salah satu banjar yang ada di Desa Peguyangan Kaja. Tujuan dari kegiatan ini agar para orang tua lebih mengetahui bagaimana gejala dari penyakit flu biasa yang berkaitan dengan penyakit ISPA dan mengetahui bagaimana cara penanggulangan dari penyakit tersebut.

Alternatif pemecahan masalah yang kiranya paling tepat diterapkan untuk mengurangi angka kejadian penyakit flu biasa, dimana flu biasa ini berkaitan dengan penyakit ISPA. Dengan melakukan upaya edukasi berupa penyuluhan kepada orang tua yang memiliki balita dengan target sasaran 30 orang selama 3bulan. Menurut kelompok kami, alternative pemecahan masalah berupa upaya edukasi dengan melakukan penyuluhan kepada orang tua yang ada di Desa Peguyangan Kaja merupakan alternative yang paling sesuai, karena tidak mungkin bagi kami menjelaskan kepada balita/anak-anak karena mereka belum terlalu mengerti untuk menjaga kesehatan maupun kebersihan secara pribadi

\section{METODE}


Metode yang digunakan dalam mencapai tujuan program tersebut adalah dengan melakukan penyuluhan berupa pemberian materi PHBS (khusus perilaku masyarakat terhadap lingkungan sekitar dan pola makan) dan materi ISPA (definisi umum, penyebab, gejala, pencegahan, dan pengobatan).

Maka dari itu, kami berusaha menjalankan suatu program yang berfokus kepada pencegahan (preventif) dengan sasaran utama kami adalah para orang tua yang memiliki balita. Tujuannya yaitu agar orang tua dapat lebih memahami bahaya dari penyakit flu yang merupakan salah satu dari gejala ISPA, sehingga para orang tua nantinya bisa menerapkan kepada anak maupun keluarga perilaku hidup sehat dan bersih agar terhindar dari penyakit yang membahayakan. Jika program ini dapat berjalan dengan baik, tentu akan berpengaruh pada penurunan angka kejadian flu biasa di Desa Peguyangan Kaja dan status kesehatan masyarakat semakin meningkat.

Evaluasi dilakukan dengan menghitung rata-rata peningkatan pengetahuan orang tua mengenai bahaya flu biasa terhadap penyakit ISPA dengan rumus sebagai berikut:

\section{$\frac{\text { J nilai post test }- \text { Jnilai pre test }}{\text { banyaknya peserta }} \times 100 \%$}

\section{HASIL DAN PEMBAHASAN}

Penyuluhan yang kami lakukan mengangkat tema "Meningkatkan Kesadaran dan Pengetahuan Orang Tua mengenai bahaya flu biasa pada anakanak terhadap penyakit ISPA di Desa Peguyangan Kaja, Banjar Paangtebel. Kami melibatkan 5 mahasiswa program studi Kesehatan Masyarakat, Universitas Dhyana Pura. Dimana dalam kegiatan penyuluhan kami menggunakan 30 responden orang tua balita. Kegiatan penyuluhan dilakukan pada hari Sabtu, 22 Mei, 26 Juni, 24 Juli 2021, dari pukul 09.00 sampai 12.00 WITA. Pemaparan materi penyuluhan dilakukan secara personal, dimana setiap anggota kelompok memberikan penyuluhan kepada 1 peserta orang tua balita.
Mekanisme kegiatan penyuluhan yang kami lakukan diawali dengan membantu persiapan posyandu, kemudian dilanjutkan dengan membagikan brosur materi kepada orang tua balita yang telah selesai mengikuti kegiatan posyandu. Sebelum dilakukan pemaparan materi oleh masingmasing anggota kelompok, peserta mengisi soal pre tes terlebih dahulu. Setelah pengisian pre tes kemudian dikumpulkan kembali dan dilanjutkan dengan pemberian materi pertama yaitu PHBS: khusus perilaku masyarakat terhadap lingkungan sekitar dan pola makan. Kemudian dilanjutkan dengan pemberian materi kedua yaitu ISPA: definisi umum, penyebab, gejala, pencegahan, dan pengobatan). Setelah pemaparan materi selesai selanjutnya, peserta melakukan pengisian soal pos tes dan mengumpulkan kembali. Berdasarkan dari kegiatan yang telah kami lakukan yaitu berupa upaya edukasi dengan melakukan penyuluhan secara langsung (personal) dengan menggunakan media brosur kepada orang tua balita yang ada di Desa Peguyangan Kaja, khusunya Banjar Paangtebel. Pada kegiatan ini bertujuan untuk meningkatkan kesadaran dan pengetahuan para orang tua mengenai Perilaku Hidup Bersih dan Sehat (PHBS) maupun bahaya flu biasa terhadap penyakit ISPA. Alternative yang kami lakukan yaitu dengan memberikan soal pre tes dan post tes kepada 30 responden. Dari hasil pendataan yang kami dapatkan dari 30 responden yang ada di Banjar Paangtebel yaitu sebagai berikut:

Tabel 1. (Pre test dan Post test)

\begin{tabular}{|c|c|c|}
\hline Responden & $\begin{array}{l}\text { PRE TEST } \\
\text { 22 Mei 2021 }\end{array}$ & $\begin{array}{c}\text { POST TEST } \\
\text { 24 Juni 2021 }\end{array}$ \\
\hline 1 & 85 & 95 \\
\hline 2 & 85 & 95 \\
\hline 3 & 95 & 95 \\
\hline 4 & 95 & 95 \\
\hline 5 & 100 & 100 \\
\hline 6 & 95 & 95 \\
\hline 7 & 50 & 75 \\
\hline 8 & 65 & 85 \\
\hline
\end{tabular}




\begin{tabular}{|c|c|c|}
\hline 9 & 30 & 60 \\
\hline 10 & 70 & 55 \\
\hline 11 & 75 & 90 \\
\hline 12 & 95 & 95 \\
\hline 13 & 60 & 45 \\
\hline 14 & 45 & 95 \\
\hline 15 & 40 & 55 \\
\hline 16 & 100 & 100 \\
\hline 17 & 70 & 100 \\
\hline 18 & 75 & 60 \\
\hline 19 & 35 & 30 \\
\hline 20 & 65 & 85 \\
\hline 21 & 85 & 85 \\
\hline 22 & 45 & 85 \\
\hline 23 & 50 & 75 \\
\hline 24 & 65 & 90 \\
\hline 25 & 40 & 95 \\
\hline 26 & 85 & 90 \\
\hline 27 & 60 & 95 \\
\hline 28 & 95 & 95 \\
\hline 29 & 80 & 90 \\
\hline 30 & 75 & 90 \\
\hline Rata-rata & $70,33 \%$ & $83,17 \%$ \\
\hline
\end{tabular}

berikan penyuluhan mengalami peningkatan sebanyak $13 \%$ dengan nilai rata-rata $83,17 \%$. Hal ini menunjukkan bahwa orang tua balita dapat memahami dan mengerti kegiatan penyuluhan yang diberikan.

Berdasarkan hasil pendataan pre test dan pos test yang diisi oleh orang tua balita di Banjar Paangtebel, dapat diketahui bahwa masih ada beberapa orang tua balita yang masih kurang memahami mengenai Perilaku Hidup Bersih dan Sehat. Dimana sebelum dilakukan penyuluhan terkait PHBS, orang tua balita ada yang tidak mengetahui kriteria penting yang harus ada di dalam makanan sehat dan bergizi serta jenis dari makanan tersebut. Kriteria penting yang harus ada di dalam makanan sehat dan bergizi tersebut adalah karbohidrat (beras merah, jagung, ubi dan gandum), lemak (ikan, alpukat, dan kacang-kacangan), vitamin (wortel, brokoli, dan bayam), serat (buncis, kangkung, manga, pisang, dan apel), mineral (sayuran hijau, buah alpukat, ikan sarden dan lobster) dan protein (telur, kacang almond, ikan, bebek, dan daging ayam). Sedangkan, sebelum dilakukan penyuluhan terkait materi Infeksi Saluran Pernafasan Akut (ISPA) dilihat dari soal pre tes yang diisi oleh orang tua balita, diketahui bahwa sebagian orang tua balita sudah mengetahui terkait penyebab, gejala, serta pengobatan dari Infeksi Saluran Pernafasan Akut (ISPA).

Dari hasil pendataan yang telah dilakukan terhadap 30 responden dapat dilihat nilai rata-rata jumlah responden yang menjawab benar dan salah pada soal pre tes dan pos tes yaitu jumlah rata-rata pada soal pre tes untuk jawaban benar adalah $69,835 \%$ dan untuk jawaban salah adalah $30,165 \%$ sedangkan untuk jawaban benar soal post tes adalah $82,50 \%$ dan untuk jawaban salah adalah $17,50 \%$ sehingga hal ini menunjukkan bahwa adanya peningkatan sebanyak $12,65 \%$ terhadap soal pre tes dan post tes yang sudah di jawab oleh 30 responden yang ada di Banjar Paangtebel. Faktor yang menyebabkan adanya peningkatan pengetahuan orang tua terhadap edukasi berupa penyuluhan 
mengenai Perilaku Hidup Bersih dan Sehat (PHBS) maupun bahaya flu biasa terhadap penyakit ISPA yaitu karena para orang tua mau mendengar dengan baik apa yang di sampaikan oleh mahasiswa sehingga pengetahuan orang tua sebelum di berikan materi masih rendah dan sesudah pemberian materi pemahaman orang tua mengalami peningkatan yang baik.

Penelitian sejenis sebelumnya dilakukan oleh Novi Asnawita dengan judul penelitiannya yaitu "Hubungan Karakteristik dan Pengetahuan Masyarakat terhadap Penyakit Infeksi Saluran Pernafasan Akut (ISPA) di UPTD Puskesmas Drien Rampak, Kecamatan Arongan Lambalek, Kabupaten Aceh Barat". Penelitian ini bersifat deskriptif analitik, dengan populasi sebanyak 532 orang dan sampel 84 orang yang menderita ISPA dan pernah berkunjung ke Puskesmas. Sampel di ambil dari populasi dengan penggunaan teknik simple random sampling. Lokasi penelitian ini di lakukan di UPTD Puskesmas Drien Rampak di Kecamatan Arongan Lambalek Kabupaten Aceh Barat. Analisis data dengan menggunakan uji ChiSquare. Pada penelitian ini melihat bahwa ada hubungan umur responden terhadap penyakit Infeksi Saluran Pernafasan Akut (ISPA), adanya hubungan pendidikan responden terhadap penyakit Infeksi Saluran Pernafasan Akut (ISPA), adanya hubungan pekerjaan responden terhadap penyakit

Infeksi Saluran Pernafasan Akut (ISPA), dan juga dari penelitian ini di dapatkan bahwa adanya hubungan pengetahuan responden terhadap penyakit Infeksi Saluran Pernafasan Akut (ISPA). Hal-hal yang membedakan penelitian ini dengan penelitian sebelumnya adalah penelitian ini membahas tentang "Meningkatkan Kesadaran dan Pengetahuan Orang Tua Mengenai Bahaya Flu Biasa Pada Anak-Anak terhadap Penyakit ISPA di Desa Peguyangan Kaja, Banjar Paangtebel “. Dalam mencapai tujuan program tersebut dengan melakukan penyuluhan berupa pemberian materi PHBS (khusus perilaku masyarakat terhadap lingkungan sekitar dan pola makan) dan materi ISPA (definisi umum, penyebab, gejala, pencegahan, dan pengobatan). Sampel diambil dari populasi dengan penggunaan teknik simple random sampling. Dalam penelitian yang di lakukan di Banjar Paangtebel ini menunjukkan bahwa adanya hubungan yang signifikan antara pendidikan dan tingkat pengetahuan para responden terhadap materi yang di sampaikan oleh mahasiswa. Hal ini dapat di lihat dari adanya peningkatan pengetahuan sebanyak $13 \%$ terhadap soal pre test dan post test yang diberikan kepada 30 responden. Menurut (Notoatmodjo, 2007), pengetahuan adalah suatu wawasan apa yang diketahui oleh masyarakat terhadap sikap dan tindakan yang diambil. Tingginya pengetahuan maka perilaku seseorang akan bertambah baik, sebaliknya jika pengetahuan seseorang kurang maka dapat perilaku kurang wajar. Sehingga keputusan yang diambil sering menimbulkan kegagalan atau kesalahan

\section{KESIMPULAN}

Dari data yang kami dapatkan di Desa Peguyangan Kaja dan berdasarkan data kunjungan pasien di Puskesmas III Denpasar Utara. Dari data tersebut penyakit flu biasa menjadi salah satu masalah kesehatan terbanyak dengan jumlah 662 orang. Alternatif pemecahan masalah yang dapat dilakukan yaitu berupa upaya edukasi dengan melakukan penyuluhan secara langsung (persona) menggunakan media brosur kepada orang tua balita, dengan menggunakan sampel sebanyak 30 orang yang ada di Desa Peguyangan Kaja, khususnya di Banjar Paangtebel. 1) Dalam kegiatan penyuluhan di Banjar Paangtebel ada 2 sesi pemberian materi yaitu materi Perilaku Hidup Bersih dan Sehat (PHBS) dan materi terkait Infeksi Saluran Pernafasan Akut (ISPA). Untuk mengetahui tingkat pengetahuan orang tua balita maka diberikan soal pre tes dan pos tes kepada 30 responden. 2) Dari hasil pre tes dan pos tes di dapatkan hasil yaitu 70,33\% jumlah benar keseluruhan dari jawaban responden sebelum diberi penyuluhan dan dari pos tes didapatkan hasil $83,17 \%$ penyuluhan Hal menunjukkan bahwa adanya peningkatan sebanyak 
13\% terhadap pengetahuan orang tua di Banjar Paangtebel sebelum dan sesudah di lakukan penyuluhan. 3) Di lihat dari hasil nilai rata-rata jumlah responden yang menjawab benar dan salah pada soal pre tes dan pos tes yaitu jumlah rata-rata pada soal pre tes untuk jawaban benar adalah $69,835 \%$ dan untuk jawaban salah adalah $30,165 \%$ sedangkan untuk jawaban benar soal post tes adalah $82,50 \%$ dan untuk jawaban salah adalah 17,50\% sehingga hal ini menunjukkan bahwa adanya peningkatan sebanyak $12,65 \%$ terhadap soal pre tes dan post tes yang sudah di jawab oleh 30 responden yang ada di Banjar Pangtebel

\section{REFERENSI}

Daroham, N.E.P. and Mutiatikum, 2009, Penyakit ISPA Hasil Riset Kesehatan Dasar (Riskerdas) di Indonesia, Puslitbang Biomedis dan Farmasi Jakarta, 50-55.

Departemen Kesehatan Republik Indonesia, 2002, Pedoman Pemberantasan Penyakit Infeksi Saluran Pernafasan Atas Akut Untuk Penanggulangan Pneumonia Pada Balita Dalam Pelita VI, Departemen Kesehatan Republik Indonesia, Jakarta.

Departemen Kesehatan Republik Indonesia, 2005, Pharmaceutical Care Untuk Penyakit Infeksi Saluran Pernapasan, Departemen Kesehatan Republik Indonesia, Jakarta.

Departemen Kesehatan Republik Indonesia, 2007, Pedoman Pengobatan Dasar Di Puskesmas, Departemen Kesehatan Republik Indonesia, Jakarta.

Sukarto R.C., Ismanto A.Y. and Karundeng M., 2016, Hubungan Peran Orang Tua Dalam Pencegahan ISPA Dengan Kekambuhan ISPA Pada Balita Di Puskesmas Bilalang Kota Kotamobagu, e-Journal Keperawatan, 4, 1-6. 